University of Nebraska - Lincoln

DigitalCommons@University of Nebraska - Lincoln

2000

\title{
RESPONSE TO CRITIQUE OF THE CLAIM OF CANNIBALISM AT COWBOY WASH
}

\author{
Patricia M. Lambert \\ Utah State University, patricia.lambert@usu.edu \\ Banks L. Leonard \\ Soil Systems Inc. \\ Brian R. Billman \\ University of North Carolina at Chapel Hill \\ Richard A. Marlar \\ University of Colorado School of Medicine \\ Margaret E. Newman \\ University of Calgary
}

See next page for additional authors

Follow this and additional works at: https://digitalcommons.unl.edu/natresreinhard

Part of the Archaeological Anthropology Commons, Ecology and Evolutionary Biology Commons, Environmental Public Health Commons, Other Public Health Commons, and the Parasitology Commons

Lambert, Patricia M.; Leonard, Banks L.; Billman, Brian R.; Marlar, Richard A.; Newman, Margaret E.; and Reinhard, Karl J., "RESPONSE TO CRITIQUE OF THE CLAIM OF CANNIBALISM AT COWBOY WASH" (2000). Karl Reinhard Papers/Publications. 34.

https://digitalcommons.unl.edu/natresreinhard/34

This Article is brought to you for free and open access by the Natural Resources, School of at DigitalCommons@University of Nebraska - Lincoln. It has been accepted for inclusion in Karl Reinhard Papers/ Publications by an authorized administrator of DigitalCommons@University of Nebraska - Lincoln. 


\section{Authors}

Patricia M. Lambert, Banks L. Leonard, Brian R. Billman, Richard A. Marlar, Margaret E. Newman, and Karl J. Reinhard 


\title{
RESPONSE TO CRITIQUE OF THE CLAIM OF CANNIBALISM AT COWBOY WASH
}

\author{
Patricia M. Lambert, Banks L. Leonard, Brian R. Billman, Richard A. Marlar, Margaret E. Newman, \\ and Karl J. Reinhard
}

\begin{abstract}
The original authors of Billman et al. (2000) are joined by three other analysts from the Cowboy Wash research team to respond to the critique of this article by Dongoske et al. (2000). Dongoske and his coauthors state that Billman et al. (2000) failed to test alternative hypotheses or to consider alternative explanations for the findings at 5MT10010 and similar sites. The original authors point out that alternative hypotheses were examined and rejected, leaving a violent episode of cannibalism as the most plausible explanation for the remains found at 5MT10010. Dongoske et al. also question many aspects of the osteological, archaeological, coprolite, and biochemical analyses that were presented in the 5MT10010 study. Our response addresses issues of data collection, procedure, and interpretation, and attempts to clarify some points that were not fully developed in the original text due to length restrictions.
\end{abstract}

Los autores de Billman et al. (2000) se onen a tres de los analistas que participaron en las investigaciones de Cowboy Wash para responder a la crítica del artículo por Dongoske et al. (2000). Dongoske et al. declaran que Billman et al. no evaluaron hipótesis alternativas, o consideraron otras explicaciones respecto a los descubrimientos de 5MT10010 y de sitios semejantes. Los autores originales responden que hipótesis alternativas para explicar los hallazgos de 5MT10010 fueron examinadas y rechazadas, dejando así un episodio violento de canibalismo como la única explicación posible. Además, Dongoske et al. cuestionan varios aspectos de los análisis osteológicos, arqueológicos, coprológicos, y bioquímicos que fueron presentados en el estudio de 5 MT10010. Nuestra respuesta se dirige a preguntas sobre de los datos, procedimientos e interpretaciones, mientras trata de clarificar ciertos puntos que no fueron completamente elaborados en el texto original debido a limitaciones de espacio.

I n their article, "Critique of the Claim of Cannibalism at Cowboy Wash,” Dongoske et al. (2000) raise a number of issues concerning our contribution "Cannibalism, Warfare, and Drought in the Mesa VerdeRegion during the Twelfth Century A.D." to the January 2000 issue of American Antiquity (vol 65 , no.1). We are pleased to have the opportunity to address their concerns and clarify aspects of data collection and analysis that may not have been clearly presented in the original text. In the interest of brevity, we focus on those issues we consider most central to the arguments set forth in the article.

At the beginning of their article, Dongoske and his coauthors (2000:179) state that, "The conclusion that cannibalism occurred at Cowboy Wash is founded, like a majority of other recent claims of cannibalism, on the assumption that perimortem modification of human bone (i.e., breakage, cutmarks, percussion striae, burning, missing vertebrae, and fragment end 'polishing') in every case is due to cannibalism." We are puzzled by this statement. We have never assumed that all cases of perimortem modification resulted from cannibalism, nor do we know of anyone involved in the debate on cannibalism in

Patricia M. Lambert - Department of Sociology, Social Work, and Anthropology, Utah State University, Logan, UT 84322-0730

Banks L. Leonard $\mathbf{m}$ Soil Systems Inc., 1121 North 2nd St., Phoenix, AZ 85004

Brian R. Billman $\bullet$ Department of Anthropology, University of North Carolina at Chapel Hill, Chapel Hill, NC 27599-3115

Richard A. Marlar $\approx$ Department of Pathology, University of Colorado School of Medicine, Denver, CO 80220

Margaret E. Newman = Department of Archaeology, University of Calgary, Calgary, AB T2N 1N4, Canada

Karl J. Reinhard $\mathbf{m}$ School of Natural Resource Sciences, University of Nebraska, Lincoln NE 68588-0368

American Antiquity, 65(2), 2000, pp. 397-406

Copyright () 2000 by the Society for American Archaeology 
the Southwest who has stated that all cases of perimortem modification were the result of cannibalism. Indeed, one of the primary results of Turner and Turner's (1999) research has been the conclusion that many such cases are, in fact, not the result of cannibalism.

We are equally puzzled by the commentators' statement that empirical data were not used to test alternative hypotheses (Dongoske et al. 2000:179). Although a formalized structure of hypothesis testing was not used in the Billman et al. article, a wide range of hypotheses were tested (such as perimortem modification by natural processes, mutilation without cannibalism, witch destruction, and hungerinduced cannibalism) before we arrived at our conclusions.

Despite this criticism, Dongoske et al. (2000:186) offer only one alternative scenario, which they claim would account for the 5MT10010 assemblage. In this scenario, they propose a genocidal attack and ransacking of the site, during which body parts accidentally fell in and near fireplaces, only to be dragged around by animals until they were finally given a hasty pseudo-burial by the reappeared survivors of the attack. In fact, we feel that several details presented in Billman et al. (2000) are clearly inconsistent with their scenario, which in essence, has already been tested and refuted. Nonetheless, we welcome the opportunity to address the comments and queries of the commentators and further elucidate the process by which we eliminated various alternative explanations.

\section{Osteology and Taphonomy}

Dongoske and coauthors (2000:182-184) raise several concerns regarding aspects of the osteological analysis of the 5MT10010 assemblage. We would like to clarify what we consider to be the five central issues, and briefly explore a few points that could not be adequately addressed in the original manuscript due to length restrictions.

\section{The Limited Nature of the Taphonomic Categories Used to Identify Cannibalism}

In his extensive treatise on cannibalism at Mancos Canyon 5MTUMR-2346, Tim White (1992) details the different types of damage that can be sustained by human bone as a result of both human and nonhuman processes. In his taphonomic study of this site, White recommends a streamlined list of 17 damage-related attributes found to be most useful in the Mancos analysis (White 1992:425). Dongoske et al. (2000:182) state that only four of these categories are discussed in our article. This is not correct. Seven categories of damage are included in the summary tables (fragmentation [wholeness], perimortem fracture, cutmarks, chopmarks, percussion pits, percussion striae, and burning). ${ }^{1}$ Four other categories (pot polish, carnivore damage, intentional scraping, and rodent gnawing) were not apparent in the assemblage. The absence of pot polish and carnivore damage is discussed in the text (Billman et al. 2000:160-161, 165). The absence of intentional scraping and rodent gnawing is not discussed in the text and should have been added to this list of negative observations. Five of the six other categories pertain to different types or attributes of perimortem fracturing (internal vault release, inner conchoidal scars, crushing, adhering flakes, peeling). All were used to identify perimortem fracturing at 5MT10010 and all were observed in the assemblage. The other category (\% intact external surface) was not recorded.

In response to the apparent lack of attention to damage detail, Dongoske et al. suggest that it is not possible from the osteological analysis as presented to determine what happened to the people whose remains were found in pithouses at 5MT10010. We disagree. Although they are correct in their observation that "not all spiral fractures are created equal," (Dongoske et al. 2000:182), only a limited number of possibilities can reasonably explain extensive perimortem fracturing in these remains. In our opinion, four different scenarios could potentially explain the formation of such an assemblage. The individuals could have been crushed in a disastrous event, such as a landslide or the collapse of a building, while they were still alive. The individuals could have been crushed by a similar event after deposition of the bodies. Camivores could have disturbed and partially consumed the remains. Alternately, humans could have been responsible for the perimortem damage.

Through careful taphonomic and osteological analysis, we were able to falsify hypotheses associated with the first three of these scenarios. Regarding the first and second explanations, there was no evidence of a disastrous event involving structural collapse at the time of abandonment. Both pithouses were largely intact, whereas the bodies were disarticulated and distributed throughout the structures. 
Microstratigraphic analysis of sediments in both pithouses indicated that they had partially filled with sterile alluvium well before the collapse of the roofs and small portions of the wall. The only episode of structural collapse that occurred before the accumulation of sediment was the collapse of the southern recess in Feature 13. However, analysis of the distribution of human remains indicates that little damage to bone occurred due to this event. In fact, long bones from this feature were among the most complete of any recovered from pithouses at 5MT10010. Structural collapse simply was not responsible for bone breakage in the pithouses. Regarding the third explanation, there was no evidence for camivore damage (Billman et al. 2000:165), and it seems unlikely that carnivores could have caused such extensive fracturing without leaving any clear osteological signatures of their involvement (see, for example, Bonnichsen and Will 1990:9-10; White 1992:152-156) .

In contrast, we were unable to find any evidence that would falsify hypotheses associated with human processing of the remains. Rather, our analysis revealed abundant evidence that the bodies were mutilated by humans. Most long bones in Feature 3 were systematically broken (e.g., Billman et al. 2000: Figure 6), and tool marks on bones from both pithouses (Features 3 and 13) provided unequivocal evidence that humans were directly involved in the disarticulation, defleshing, and reduction of these bodies. Osteological evidence such as heavy fracturing from a blow directed at the mouth of the 7.5year-old in Feature 13 (Billman et al. 2000: Figure 8) further attested to the violent nature of the episode.

Dongoske et al. also express concern over the lack of detail regarding patterns of burning. For the sake of brevity, data on burning were presented in a simple "presence/absence" format in Tables 6 and 7. Burning was described in greater detail in the text (Billman et al. 2000:165-166), based on a very detailed analysis of burning patterns in human remains from 5MT10010 pithouses. One clarification of this text: for burned elements, post-burn breakage was evident in most cranial and some limb elements; in other cases, as indicated in the text, limbs were clearly broken before fire exposure. As neither pithouse was burned (Billman et al. 2000:157), structural burning cannot explain these patterns. The most important aspect of the burning patterns was the light-to-moderate burning of broken ends and thinly fleshed surfaces that predominated where burning was present. Calcination and other signs of exposure to high temperatures (see Ubelaker 1984:34-36) were completely absent, on the other hand, indicating that body parts were exposed to fire while fleshed for a time period sufficient to cook but not destroy the flesh.

\section{The Focus on a Different Unit of Analysis}

Dongoske et al. express disappointment that the data are not comparable with other purported cannibalism assemblages (e.g., Turner and Turner 1999; White 1992). This is true for by-piece analysis, but not necessarily for other levels of analysis. The analysis was conducted over a limited time frame, so decisions were made regarding which method could provide the best information for interpreting events at 5MT10010. The relatively small number of individuals and the separation of these individuals into two discrete and non-overlapping contexts allowed for significant reconstruction of three skeletons and portions of the other four (see Lambert et al. 2000). This rare opportunity to look at the treatment of individuals (e.g., Billman et al. 2000: Figure 4) strongly influenced the decision to focus on skeletal elements and individuals, rather than on pieces and skeletal elements, as the primary units of analysis.

We also should have pointed out that this collection was not directly comparable to 5MTUMR-2346 or many other such collections from the outset. Not only were the deposits at 5MT10010 in primary and contained contexts, but more importantly, all primary cultural sediments from the pithouses were screened with 1/4-inch (6.4-mm) mesh. All fragments visually assessed to be about $1 \mathrm{~cm}$ or larger were counted. These practices yielded hundreds of small fragments. Although the bone beds that produced the Mancos Canyon material were pedestaled during excavation, screening was not systematically employed with that assemblage (Larry V. Nordby, personal communication 2000). Furthermore, it appeared that the processed bodies at the site had been disarticulated elsewhere and then brought to this location and thrown into the back of the pueblo (Nordby 1974). White (1992:102-104) is very clear on the size bias evident in the Mancos Canyon assemblage (most $>3 \mathrm{~cm}$ ). 
Proposed Problems with Accounting of the Pieces from the 5MT10010 Assemblage

Tables 6 and 7 of our article (Billman et al. 2000) provide information on the identified portion of the 5MT10010 pithouse human bone assemblages. Accounted for are 764 pieces, or 47 percent of the 1629-piece assemblage by count, not 25 percent, as indicated by Dongoske et al. (2000:158). Most of the remaining pieces were small and/or lacked definitive features. ${ }^{2}$

We agree with the commentators that the text (Billman et al. 2000:183) regarding the absence of adult leg bones in the Feature 3 pithouse is confusing. To clarify, only 19 specifically identifiable fragments (all $\leq 11.5 \mathrm{~cm}$, none conjoinable) representing a minimum of five adult leg long bones were apparent in this assemblage. These 5 bones represent only 15.6 percent of the leg bones that would be expected from four adults $(n=32)$. We found this particularly curious, because all six long bones and one patella from the Feature 3 adolescent were accounted for, albeit incompletely. ${ }^{3}$ The issue of the "missing" leg bones was raised for two reasons. First, it was clear that not all bones from the five identified individuals had been dumped down the shaft or tossed/placed on the floor of the pithouse at abandonment. Second, two weathered femur fragments-the only human bone recovered fromFeature 15-suggested one explanation for the "missing" bones: they were left on the surface after processing and lost to the archaeological record through weathering and other natural processes (Lambert et al. 2000).

\section{The Presentation of Data by Pithouse} Rather than by Site

We are puzzled by the criticism that "the analysis of osteological data by element, broken out by the two assemblages, masks patterns that might [be] more understandable with an element-by-element analysis of the total site assemblage" (Dongoske et al. 2000:183), especially when the commentators specifically call for intra-assemblage analysis later in the article (Dongoske et al. 2000:188). Here we more fully develop what we consider to be the significance of these two assemblages.

As indicated in Billman et al. (2000:162), the mutilated human remains from 5MT10010 came from two distinct and non-overlapping contexts. We know this because it was possible to reconstruct a significant portion of three subadults, the only subadults recovered from these pithouses. No extra subadult bones were evident in either context, nor were any adult bones observed among the remains of the two subadults (the only apparent individuals) in Feature 13 (Lambertet al. 2000). Further, although the human bodies in these two pithouses derived from the same abandonment event (Billman et al. 2000:156) and shared important damage characteristics that suggested human processing for cannibalism, they also differed in some intriguing ways. These two pithouse assemblages thus offered a unique opportunity to explore the range of behavior that might be expected in violent acts culminating in anthropophagy (Lambert et al. 2000).

The long bones are useful for examining these differences (Table 1). All of 29 long bones (48.3 percent of expected total) identified in Feature 3 were broken and all showed evidence of size reduction; the largest long bone fragment from this assemblage was $14 \mathrm{~cm}$. Most (82.8 percent) appeared to have been systematically reduced by breakage at the ends of the shafts. The others were also clearly reduced, but the systematic nature of this reduction could not be verified due to their very incomplete condition. A total of 23 long bones (95.8 percent of expected total) was identified in the Feature 13 assemblage. Most (74 percent) had perimortem breaks, but half (52 percent) were essentially whole ( $>90$ percent), and those that were broken up (most notably the humeri and femora) had no systematic pattern of breakage. The largest long bone piece from this assemblage was $28.9 \mathrm{~cm}$, twice the length of the longest piece from Feature 3. Although there were age differences in the composition of these assemblages, these do not explain differences in the relative wholeness of bones. The long bones $(n=12)$ of the 11-year-old in Feature 3 were processed in the same manner as were two reconstructed sets of adult arm bones $(n=12)$ from that pithouse, and were processed very differently from the long bones of the 7.5-year-old and 14-year-old in Feature 13. Further, the bones found in Feature 3 appear to have been processed on the surface and most subsequently disposed of down the ventilator shaft. Those found in Feature 13 appear to have been processed within the pithouse, where they were left in a number of different contexts.

Also notable was the positive correlation between 
Table 1. Comparison of Long Bone Attributes in Human Remains from Feature 3 and Feature 13 at 5MT10010.

\begin{tabular}{ccccccc}
\hline $\begin{array}{c}\text { Pithouse } \\
\text { feature }\end{array}$ & $\begin{array}{c}\text { Number of } \\
\text { Long Bones }\end{array}$ & $\begin{array}{c}\text { Wholeness }^{\mathrm{a}} \\
(>90 \%)\end{array}$ & $\begin{array}{c}\text { Wholeness }^{\mathrm{a}} \\
(>75 \%)\end{array}$ & Burning & $\begin{array}{c}\text { Perimortem } \\
\text { Breakage }\end{array}$ & $\begin{array}{c}\text { Cut } \\
\text { Marks }\end{array}$ \\
\hline 3 & 29 & $0 \%$ & $0 \%$ & $3.4 \%$ & $100.0 \%$ & $27.6 \%$ \\
13 & 23 & $52.2 \%$ & $60.9 \%$ & $73.9 \%$ & $73.9 \%$ & $13.0 \%$ \\
\hline
\end{tabular}

${ }^{\mathrm{a}}$ Based on maximum, unbroken dimension of bone. Measurement excludes unfused epiphyses.

burning and wholeness (Table 1). In Feature 3, where all long bones were reduced in size, only one (3.4 percent) showed possible signs of direct heat exposure. In Feature 13, where 61 percent of the long bones were $>75$ percent complete (and unbroken), 74 percent showed signs of burning (57 percent of those $>75$ percent whole). We have argued elsewhere (Lambert et al. 2000) that these differences suggest two distinct processing strategies: stewing in cooking pots and roasting directly over the fire. Both are consistent with cannibalistic practices in Fiji and the Cauca Valley of Colombia, where war-related anthropophagy is well documented in historic accounts (Cameiro 1990:202-207). The best osteological evidence for cooking of human flesh at 5MT10010 is the light-to-moderate burning patterns most evident in the Feature 13 assemblage. The osteological evidence for stewing in the Feature 3 assemblage is suggestive, but more circumstantial, and verification of this practice must ultimately rely on other lines of evidence that can place human flesh in cooking pots (Marlar et al. 2000). Why anthropophagy occurred in two distinct, but contemporaneous, contexts at 5MT10010 remains to be explained.

In sum, the archaeological and osteological evidence from 5MT10010 indicates that the perpetrators were not behaving according to a ritualized coda or a single, secular strategy, when processing these human bodies (see Lambert et al. 2000). The bioarchaeological implication of this observation is that not all collections of human remains processed for consumption need look the same. An expectation of uniformity with regard to the composition and damage characteristics of such collections may be unnecessarily limiting or erroneous.

\section{The Lack of Consideration for Possible Variability} and its Meaning in this and Other Disarticulated Bone Assemblages from the American Southwest.

The Ute Mountain Ute Irrigated Lands Archaeological Project provided an excellent opportunity to explore a range of behaviors that can result in perimortem damage to human bodies (Lambert 1999,
2000). Mutilation was apparent at several Pueblo IIIII sites on the southern piedmont of Sleeping Ute Mountain. Based on our study of these remains, we fully agree with Dongoske et al. that mutilation was not always associated with cannibalism in this region. Three individuals from sites dating before the abandonment of 5MT10010 (A.D. 1075-1125) and four individuals dating to the final occupation of the southern piedmont (A.D. 1225-1280) showed signs of human or carnivore-induced perimortem damage, but none had the combination of traits researchers have used to identify acts of cannibalism (see Turner and Turner 1999; White 1992). Only at 5MT10010 did the archaeological and osteological evidence converge on a single explanation: violence and cannibalism. Osteological evidence from the larger UMUILAP sample (63individuals) did suggest, however, that the period from A.D. 1075-1280 was a time of increasingly intense violence on the southern piedmont, which would lend credence to our interpretation of the violent nature of events at 5MT10010 (Lambert 2000).

\section{Blood Residue Analysis: Evidence for Cannibalism?}

In evalua ting the evidence for protein residues on cutting tools from 5MT10010, Dongoske et al. question the ability of biochemical methods to detect protein residues on ancient tools. These doubts appear to be based on several articles that have appeared over the last five years, which concluded that the detection of proteins on archaeological materials was difficult or impossible (Eisele 1994; Eisele et al. 1995; Loy and Dixon 1998). The authors of these articles were unable to detect protein residue, so they concluded that researchers reporting positive results were obtaining false positives. However, biochemists evaluating these articles haveidentified several flaws in the presented research (Marlar et al. 1995; see also Newman et al. 1996). When stored in inappropriate containers (such as glass or polystyrene), for example, the eluted protein can adsorb to the vessel surface and thus not be detected in the 
assay. The method of residue removal from an artifact can also reduce the sensitivity of the assay; soaking an artifact only in water or buffer, even for periods of up to 24 hours, will remove less than 20 percent of the residue, whereas the use of buffers alongside detergents and sonication can remove up to 80-90 percent of the residue. Unfortunately, if biochemical studies are poorly designed and based on poor methodologies, they can produce erroneous (negative) results.

The method used to test for blood on 14 artifacts from Feature 13 at 5MT10010 was cross-over immunoelectrophoresis (CIEP). CIEP is an immunological method with a long history of use in forensic laboratories, and known for its high degree of specificity (Newman 1989; Newman et al. 1996). Further, the use of commercial antisera produced for forensic medicine in this study eliminated the possibility of cross-reactivity or false positives due to antisera. The CIEP analysis detected human blood immunoglobulins on two cutting tools from Feature 13. Because certain substances in soil may precipitate antisera, and thus result in false positive results, two control sediment samples from Feature 13 also were analyzed as part of this analysis; both control samples tested negative for human blood (Newman 2000).

Dongoske et al. (2000:184) suggest that the human blood detected on the cutting tools from 5MT10010 may have resulted from "a prehistoric 'accident' in tool manufacture or resharpening." Using the ELISA (Enzyme-Linked Immuno-Sorbent Assay), the most sensitive immunological method for detecting the blood of specific species, Richard Marlar has analyzed over 750 artifacts from several sites and found that only .26 percent (2/750) were positive for human blood. From the hundreds of modern lithic artifacts made by or for his research team, less than .1 percent tested positive for human blood. If a small amount of blood from a flintknapper's injury did adhere to a lithic artifact, it would most likely be removed with subsequent usage of the tool. When blood is found on tools, it most likely derives from the final usage of the artifact. Only .26 percent of artifacts tested positive for human blood using the ELISA technique, which is 10 times more sensitive than CIEP. Therefore, the relatively high frequency of tools with human blood identified in this 14-piece assemblage (14.3 percent) is all the more remarkable.
It is also important to reiterate that we already know that cutting tools were used in the processing of these bodies, based on osteological evidence of defleshing cut marks. The biochemical data simply identified a minimum of two tools that were likely used for this purpose.

\section{Fecal Evidence for Cannibalism?}

Dongoske et al. express similar concerns regarding potential problems with the method used to analyze the human coprolite from 5MT10010. As indicated in Billman et al. (2000:167), the coprolite from 5MT10010 was analyzed for the presence of human muscle tissue using ELISA. ELISA is the most sensitive method for identifying species-specific proteins. It is 10 to 1000 times more sensitive than other reported methods used in some archaeological research. The ELISAbased assay of this coprolite detected significant concentrations of human myoglobin (i.e., a protein specific to human muscle tissue) (Marlar 1998). Details pertaining to the biochemical assessment of this specimen and of control samples from both modern and archaeological contexts are presented in an article currently under review (Marlar et al. 2000).

Dongoske et al. correctly observe that protein material degrades over time, and suggest that myoglobin would have completely degraded in 800 years-thus calling into question the positive results obtained during this analysis. Marlar has detected hemoglobin residue on Archaic projectile points from 7,000-3,000 B.P. (Hammond and Rathbun 1998; Marlar et al. 1999). Hemoglobin survives for long periods of time (even longer than plasma proteins or albumin) because it is present in red blood cells (essentially sacks) that dry onto or within the artifact, thus protecting the encapsulated proteins from degradation. Myoglobin also is present in cells, and is preserved in a similar fashion.

Dongoske et al. (2000:184) also wonder if improper handling could have created false positive results for myoglobin, because foreign proteins are "found in abundance on everyone's hands." While it is the that proteins are present on the skin surface, myoglobin is found only in skeletal and cardiac muscle cells. It is not a blood protein and is not present on the skin. After extensive testing, Marlar has never found myoglobin contamination from the handling of artifacts. 


\section{Biological Origin of the Coprolite}

A more central question raised by Dongoske et al. pertains to the biological origin of the coprolite. Although human specific probes can be used to test the biological origin of coprolites, these chemical and molecular probes are not consistently successful in recovering species-specific signatures in coprolites (but see Sutton and Reinhard 1995). Therefore, determination of biological origin is based on longstanding methods of morphological and content analysis. The identification must take place at four different levels of analysis: 1) excavation, 2) initial examination, 3) during chemical reconstitution, and 4) during analysis of coprolite contents (Reinhard and Bryant 1992).

Excavation context is an important consideration in some cases. Latrine deposits, for example, imply human behavior. At 5MT10010, the context was more complicated because the coprolite potentially related to behaviors (i.e., the butchering and consumption of people) that took place in another pithouse at the site. However, both the deposition of the coprolite and the mutilation of the corpses were associated with the last activities at the site. These associations provided circumstantial evidence that the coprolite was of human origin.

Initial examination supported the human attribution of this coprolite. The morphology of animal feces is distinct to taxon, and human coprolites from the Colorado Plateau can be sorted from most animal coprolites based on morphology during initial examination. However, confusion of human and dog coprolites can occur at this stage of analysis. Therefore, biological determination problems really revolve around separating. human specimens from dog specimens. Fortunately, dogs, like other carnivores, produce a mucosal coat around the feces that protects the intestinal wall (Reinhard and Bryant 1992). This dries to a crust surrounding the coprolite that persists in archaeological contexts. In a few cases, however, dog coprolites can be still be confused with human coprolites. It is in the next state of analysis, reconstitution, that human-like dog coprolites can be identified.

If a mucous coat is present, immersion in a .5percent trisodium phosphate solution will rehydrate this feature even if it was not visible in preliminary examination. The coat appears as a thin, somewhat adherent, translucent, light gray film. As dog copro- lites continue to rehydrate, the solution color changes from colorless to light amber. The presence of both the mucous and the amber color is typical of dogs. A small percentage of human coprolites turn the solution a light amber color, so coloration alone is not a definitive indicator. Further processing through disaggregation and screening reveals additional evidence of origin. Once the microscopic particles have been screened out of the disaggregated residues, they are sedimented by gravity in glass vials. One aspect of the microscopic residue of dog coprolites is a gray, paste-like material that sediments to the bottom of the vial. This material is a consistent occurrence in dog feces and coprolites, but not in human feces or coprolites.

Dog coprolites are further distinguished from human coprolites by dietary constituents. All dog coprolites and feces examined by Karl Reinhard $(\sim 50)$ contain dog hair. The hair fragments often are frayed at both ends, presumably from nibbling behavior associated with grooming. Human coprolites less commonly contain hair, and lack nibbled dog hair. Although the coprophagous habits of ancient dogs can introduce human dietary remains into $\operatorname{dog}$ feces, prehistoric dogs ate a variety of other items, such as cordage and sections of rabbit fur robes, that have not been identified in human coprolites (Reinhard 2000). The absence of a mucosal coat, gray paste-like sediments, unusual dietary items, and nibbled dog hair is evidence against a canid origin for this coprolite.

The coprolite is unlikely to derive from a dog or othercamivore for other reasons as well. Camivores have camassial molars to fragment bone so that it can be swallowed. Therefore, bone fragments are ubiquitous in the feces of carnivorous carnivores (Vaughan 1978:213-215). This also is true of scavenging camivores such as coyotes. Coyote coprolites reflect their omnivorous habits and generally contain more plant debris than animal debris; they also have a lighter color and texture than coprolites of humans and dogs, but have a mucous coat and other components common to all camivores. The coprolite is not consistent with camivorous or omnivorous animals in the order Camivora.

Finally, in response to the query, "Isn't anyone else bothered by the fact that there were virtually no plant remains in the fecal material?" (Dongoske et al. 2000:185), we reiterate the point that the analysis of the suspected cannibal coprolite was aimed at 
testing the hypothesis that the coprolite was derived from a very unusual meal(s), one composed of human flesh. The discovery of ordinary Anasazi food items such as starch granules and phytoliths in the coprolite (see Minnis 1989; Reinhard 1992) would have falsified the hypothesis. The absence of ordinary Anasazi food items, on the other hand, supports the "cannibal" hypothesis. Therefore, the hypothesis that the coprolite was derived from cannibal activity was not refuted, and all levels of analysis described above support a human attribution for this specimen.

\section{Aspects of Archaeological Context}

Dongoske and coauthors (2000:185) challenge the interpretation of the sudden mode of abandonment at 5MT10010 based on aspects of archaeological context. They focus in particular on the apparent inconsistency of the dumping of fresh trash into the ventilation system of an occupied structure, as implied by the description of the southern chamber floor in Feature 3 as covered by "a layer of trash that was deposited well before abandonment" (Billman et al. 2000:158). The confusion here is the fault of the authors' attempts to shorten the article. In the site report (Leonard et al. 2000), the deposit underlying the bone pile in the southern chamber is described in detail. The underlying deposit was not a primary trash deposit, but rather, a layer of "trashy" fill. Sometime during the occupation of Feature 3, the southern recess and chamber were remodeled. The remodeling and repair included the use of secondary cultural fill containing artifacts and refuse (Leonard et al. 2000). On the southern piedmont of Ute Mountain, deposits of sediment containing discarded artifacts were common in ventilator systems and side chambers of pitstructures, including those whose main chamber floors were clean and void of refuse when the structure was abandoned (Kleidon 2000). Nonetheless, other lines of evidence also indicate that Feature 3 was in good repair and in use at the time of site abandonment.

Dongoske et al. (2000:185) wonder about the extent to which bone redeposition was caused by animals or fluvial processes at the site. There is no evidence for the involvement of either carnivores or rodents in the formation of these deposits. Further, the site report (Leonard et al. 2000) describes in exhaustive detail the formation processes that effected the contexts of the human bone assemblages in the structures. Indeed, some bones were displaced from their original positions by natural processes. For example, the isolated fragments in the northeastern part of the southern chamber of Feature 3 apparently rolled or were washed from the bone pile into those positions. However, it is extremely unlikely that all the fragments on the pithouse floors were washed into the positions where they were found because: a) they were in direct floor contact or were in direct contact with objects that were in direct floor contact, with no sedimentsunderneath; $b$ ) the fragments were found widely dispersed on the floors, especially in Feature 3, rather than in concentrations around the edges of the floors or under the roof entries; c) evidence of size-sorting was absent among these fragments; and d) these fragments were not weathered from exposure to the elements like the two fragments recovered from Feature 15, which were found in floor fill and ventilator fill and had apparently washed into the structure after abandonment. Rather, the distribution of floor contact fragments indicates that they were deposited in those positions at the time of site abandonment or very soon afterward. These same indicators imply that the assemblages were not the result of human activities occurring any great length of time after the site was abandoned.

The seemingly deliberate placement of the two scapulae on the floor of Feature 3 was mentioned by Billman et al. (2000:159) because this was the only possible indication of ritualism in the abandonment contexts of 5MT10010. Except during warfare or catastrophe, the disposition of human remains is perhaps one of the most typically ritualized activities in which humans regularly participate. Therefore, it is the apparent lack of obvious ritualism that we find remarkable at 5MT10010 and similar sites, not the presence of one possibly ritualistic detail in the placement of two items in an assemblage of over a thousand items. The distribution of the other primary context human remains appears casual and haphazard; no sign was present that any effort was expended in gathering up or covering remains (other than the act of dumping them down the ventilator shaft), or of placing them in any obvious order after they were processed and discarded. Of course, there is no reason why cannibalism could not be a ritualized activity. The lack of ritualism in itself does not support or refute the hypothesis that cannibalism occurred, but the lack of it does make explanations such as secondary burial or "ritualized dismemberment" and other formulaic attempts 
to achieve spiritual effects through the destruction of human bodies seem less likely.

\section{Cannibalism and the Nature of Scientific Proof}

We wholeheartedly agree with the position advocated by Dongoske et al. that controversial claims require the highest standards of evidence, especially when those claims potentially affect descendent groups. This is true for claims of prehistoric cannibalism, as well as for equally controversial explanations such as genocidal violence (Dongoske et al. 2000:186). In retrospect, the article should have stated more clearly that there is very little evidence of the practice of cannibalism by Puebloan people or other indigenous groups in the Southwest in the historic or late prehistoric period. The near absence of this practice after A.D. 1200 is noted by Billman et al. (2000:173); however, this point may not have been sufficiently emphasized, and it is one of the most important results of the article's review of possible incidents of cannibalism in the Southwest.

Although we agree that high standards of evidence are required in this case, at times in their critique, Dongoske et al. (e.g., 2000:180) seem to demand absolute proof. Yet no theory can be scientifically proven; scientific theories advance through the falsification of hypotheses. Simply proposing alternative explanations does not suffice to reject an explanation. In our study, we attempted to falsify several alternative hypotheses for the occurrence of disarticulated and modified human remains at 5MT10010. After elimination of other plausible explanations, we were left with a theory that the remains at Cowboy Wash resulted from raiding and cannibalism. Individuals interested in rejecting our explanation face a relatively straightforward task: falsify the hypotheses derived from our theory. We welcome the empirical testing of our explanation. Finally, we hope that issues raised in these articles will contribute to the investigation of larger issues of population displacement, violence, migration, and abandonment in the Southwest and beyond, rather than simply to the debate over the presence or absence of cannibalism in one particular area of the world at one particular moment in time.

\section{References Cited}

Billman, B. R., P. M. Lambert, and B. L. Leonard

2000 Cannibalism, Warfare, and Drought in the Mesa Verde Region during the Twelfth Century A.D. American Antiq- uity 65:145-178.

Bonnichsen, R., and R. Will

1990 Cultural Modification of Bone: The Experimental Approach in Faunal Analysis. In Mammalian Osteology, edited by B. M. Gilbert, pp. 7-30. Missouri Archaeological Society, Columbia.

Carniero, R. L.

1990 Chiefdom-level Warfare as Exemplified in Fiji and the Cauca Valley. In The Anthropology of War, edited by J. Haas, pp. 190-211. Cambridge University Press, Cambridge.

Dongoske, K. E., D. L. Martin, and T. J. Ferguson

2000 Critique of the Claim of Cannibalism at Cowboy Wash. American Antiquity 65:179-190.

Eisele, J. A.

1994 Survival and Detection of Blood Residue Analysis on Stone Tools. Technical Report 94-1. Department of Anthropology, University of Nevada, Reno.

Eisele, J. A., D. D. Fowler, G. Haynes, and R. A. Lewis

1995 Survival and Detection of Blood Residue Analysis on Stone Tools. Antiquity 69:36-46.

Hammond, W., and F. Rathbun

1998 Preliminary Report of the 1998 Excavations at the Swallow Site (5JF321). Colorado Archaeological Society, Denver.

Kleidon, J.

2000 5MT9541: A Late Pueblo III Habitation Site. In The Puebloan Occupation of the Ute Mountain Piedmont: Late Pueblo II-Early Pueblo III, Early Pueblo III, and Late Pueblo III Habitation Sites, edited by B. R. Billman. Publications in Archaeology No. 22, Vol. 3. Soil Systems Inc., Phoenix. In press.

Lambert, P. M.

1999 Human Skeletal Remains. In The Puebloan Occupation of the Ute Mountain Piedmont: Environmental and Bioarchaeological Studies, edited by B. R. Billman, pp. 111-161. Publications in Archaeology No. 22, Vol. 5. Soil Systems Inc., Phoenix.

2000 Violent Injury and Death in a Pueblo II-III Sample from the Southern Piedmont of Sleeping Ute Mountain, Colorado. American Journal of Physical Anthropology, Supplement 30:205.

Lambert, P. M., B. R. Billman, and B. L. Leonard

2000 Explaining Variability in Mutilated Human Bone Assemblages from the American Southwest: A Case Study from the Southern Piedmont of Sleeping Ute Mountain, Colorado. International Journal of Osteoarchaeology 10:49-64.

Leonard, B. L., K. Mc Andrews, and P. M. Lambert

2000 5MT10010. In The Puebloan Occupation of the Ute Mountain Piedmont: Late Pueblo II-Early Pueblo III, Early Pueblo III, and Late Pueblo III Habitations Sites, edited by B. R. Billman. Publications in Archaeology No. 22, Vol. 3. Soil Systems Inc., Phoenix. In press.

Loy, T. H., and E. J. Dixon

1998 Blood Residue on Fluted Points from Eastern Beringia. American Antiquity 63:21-46.

Marlar, R.

1998 Letter Report Summarizing the Results of Human Myoglobin ELIS A Testing of a Human Coprolite and Artifacts from 5MT10010, Southwestern Colorado. Manuscript on file, Soil Systems Inc., Phoenix.

Marlar, R., L. Scott-Cummings, and K. Puseman

1995 Protein Residue Analysis of Archaeological Materials: Comments on Criticisms and Methods. Southwestern Lore 61(2):27-37.

Marlar, R., M. Kerklo, and J. E. Marlar

1999 Report on Protein Residue Analysis from Sites on the Trans Colorado Pipeline. Report submitted to Centennial 
Archaeology Inc., Fort Collins, Colorado.

Marlar, R. A., B. L. Leonard, B. R. Billman, P. M. Lambert, and J. E. Marlar

2000 Biochemical Evidence of Cannibalism at a Prehistoric Puebloan Site in Southwestern Colorado. Manuscript on file, Department of Pathology, University of ColoradoSchool of Medicine, Denver.

Minnis, P. E.

1989 Prehistoric Diet in the Southwest: Macroplant Remains from Four Corner's Feces. American Antiquity 54:543-563.

Newman, M. E.

1989 The Identification of Protein Residues on Lithic Artifacts from a Stratified Boreal Forest Site. Canadian Journal of Archaeology 13:119-132.

2000 Immunological Analysis of Lithic Artifacts from 5MT10010. In The Puebloan Occupation of the Ute Mountain Piedmont: Late Pueblo II-Early Pueblo III, Early Pueblo III, and Late Pueblo III Habitation Sites, edited by B. R. Billman). Publications in Archaeology, No. 22, Vol. 3. Soil Systems Inc., Phoenix. In press.

Newman, M. E., H. Ceri, and B. Kooyman

1996 The Use of Immunological Techniques in the Analysis of Archaeological Materials-A Response to Eisele; With Report of Studies at Head-Smashed-In Buffalo Jump. Antiquity 70:677-682.

Nordby, L. V.

1974 Excavation of Sites 5MTUMR-2343, -2345, and -2346, Mancos Canyon, Ute Homelands, Colorado. Report submitted to the Bureau of Indian Affairs, Contract No. MOOC14201337.

Reinhard, K. J.

1992 The Impact of Diet and Parasitism on Anemia in the Prehistoric West. In Diet, Demography and Disease: Changing Perspectives of Anemia, edited by P. Stuart-McAdam and S. Kent, pp. 219-258. Aldine deGruyter, New York.

2000 Results of Analysis of a Human Coprolite from 5MT10010, Southwestern Colorado. In ThePuebloan Occupation of the Ute Mountain Piedmont: Late Pueblo II-Early Pueblo III, Early Pueblo III, and Late Pueblo III Habitation Sites, edited by B. R. Billman. Publications in Archaeology, No. 22, Vol. 3. Soil Systems Inc., Phoenix. In press.

Reinhard, K. J., and V. M. Bryant

1992 Coprolite Analysis: A Biological Perspective on Archaeology. In Advances in Archaeological Method and Theory, vol. 4, edited by M. B. Schiffer, pp. 245-288. University of Arizona Press, Tucson.
Sutton, M. Q., and K. J. Reinhard

1995 Cluster Analysis of the Coprolites from Antelope House: Implications for Anasazi Diet and Cuisine. Journal of Archeological Science 22:741-750.

Turner, C. G. II, and J. A. Turner

1999 Man Corn: Cannibalism and Violence in the Prehistoric American Southwest. University of Utah Press, Salt Lake City.

Ubelaker, D. H.

1984 Human Skeletal Remains. Rev. ed. Taraxacum, Washington, D.C.

Vaughn, T. A.

1978 Mammology. Saunders College, Philadelphia.

White, T. D.

1992 Prehistoric Cannibalism at Mancos 5MTUMR-2346. Princeton University Press, Princeton.

\section{Notes}

1. Percussion pits and percussion striae were combined in the tables (but not in the analysis). Two corrections to Table 6: the MNI for lumbar vertebrae should be 3; the perimortem breakage value for fibulae should be 100 percent.

2. NISP values in this study include all identified pieces by element, whereas those in White (1992) include only those pieces with identifiable attributes. Pieces not included in the Feature 3 summary table include: 3 teeth ( 2 incisors and 1 canine), 177 unidentified long bone shaft fragments, and 385 unidentified fragments (including only 2 burned fragments). Pieces not included in the Feature 13 summary table include 1 cranial fragment, 1 tooth fragment, 2 vertebrae fragments, 20 rib fragments, 1 metatarsal fragment, 2 hand/foot fragments, 21 long bone shaft fragments, and 252 unidentified fragments, none of which could be specifically attributed to individuals " $\mathrm{A}$ " or " $\mathrm{B}$."

3. None of these bones was complete; the long bones were represented by 16 fragments and the patella by one fragment. One tibia fragment from the Feature 3 assemblage was not attributed to a specific age category.

Received March 30, 2000; accepted April 4, 2000. 